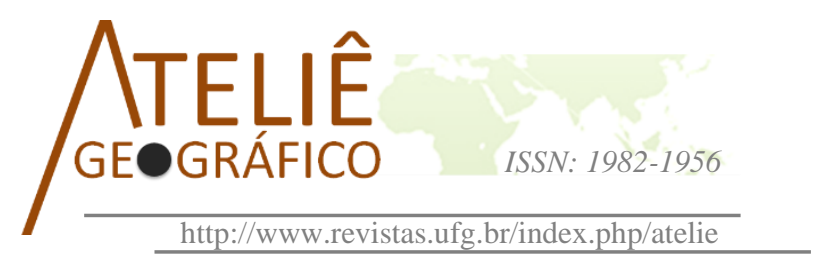

\title{
Wari': conversão, identidade cultural e marcadores territoriais na Terra Indígena Igarapé Laje em Rondônia
}

\author{
Wari': conversion, cultural identity and territorial markers \\ in the Terra Indígena Igarapé Laje in Rondônia State \\ Wari': conversion, identité culturelle et marqueurs \\ territoriaux en Terre Indigène Igarapé Laje dans l'État de \\ Rondônia
}

\author{
Francisco Marquelino Santana \\ Universidade Federal de Rondônia \\ marquelino@hotmail.com \\ Josué da Costa Silva \\ Universidade Federal de Rondônia \\ jcosta@unir.br \\ Adnilson de Almeida Silva \\ Universidade Federal de Rondônia \\ adnilson@unir.br
}

\begin{abstract}
Resumo
O presente artigo procura analisar o modo de atuação das missões evangelizadoras na Aldeia Laje Velho, especificamente conduzidas pelas Missões Novas Tribos do Brasil - MNTB, que aproximadamente há cinquenta anos dedicam-se em converter esse coletivo indígena à religiosidade cristã. Outro aspecto aqui analisado é a identidade cultural Wari', suas experiências ancestrais, sua cosmogonia, territorialidade e todo seu aporte simbólico com a natureza. Em seguida relacionamos esses dois aspectos aqui mencionados com os marcadores territoriais estruturantes e estruturadores, de modo que procuramos identificar e distinguir quais ações são consideradas originárias à coletividade e quais ações são características da sociedade envolvente. $\mathrm{O}$ trabalho é resultante de uma atividade de campo realizada com o povo Wari' na Terra Indígena Igarapé Laje, localizada entre os municípios de Guajará Mirim e Nova Mamoré no Estado de Rondônia. Apresenta em seu contexto as percepções obtidas e suas respectivas análises alicerçadas em abordagens metodológicas construídas por meio de referenciais bibliográficos, entrevistas, em que a fenomenologia constitui-se como base principal às análises em questão.
\end{abstract}

Palavras-chave: Conversão. Identidade cultural. Marcadores Territoriais. Wari'. 


\begin{abstract}
The present article analyzes evangelical conversion performed by the New Tribes Missions of Brazil - MNTB at the Laje Velho Village, which have, for about fifty years, dedicated themselves to convert the Wari' indigenous people to Christianity. Taking into account the Wari' symbolic contribution to nature, including it's cultural identity, their ancestral experiences and cosmogony; we relate it to the structural and structuring territorial markers, so as to identify and distinguish which actions are considered as originating in the collectivity and which actions are characteristic of the involving society. The article is the result of fieldwork and interviews conducted with the Wari' people in the Terra Indígena Igarapé Laje, located between the municipalities of Guajará-Mirim and Nova Mamoré in Rondônia State. It presents the perceptions and respective analyses based on methodological approaches built through bibliographic references, in which phenomenology is the main theoretical basis for analyzing the problem.

Keywords: Evangelical Conversion. Cultural identity. Territorial Markers. Wari'

\section{Résumé}

Cet présent article vise à analyser la manière d'opérer les missions évangélisatrices dans le Villaje Laje Velho, spécifiquement menées par les Missions Nouvelles de Tribus du Brésil - MNTB, il y a environ une cinquantaine d'années consacrées à convertir ce collectif indigène à la religiosité chrétienne. Autre aspect ici analysé c'est l'identité culturelle Wari', ses expériences ancestrales, sa cosmogonie, sa territorialité et toute sa contribution symbolique à la nature. Puis nous rapportons ces deux aspects ici mentionnés avec les marqueurs territoriaux structurations et designers, donc nous cherchons à identifier et distinguer quelles sont les actions qui sont considérées originaires dans la collective et quelles sont les caractéristiques des actions de la société environnante. Le travail est le résultat d'une activité de terrain effectuée avec le peuple Wari' en Terre Indigène Igarapé Laje, située entre les communes de Guajará-Mirim et Nova Mamoré dans l'État de Rondônia. Présente dans son contexte les perceptions obtenues et ses respectives analyses fondées sur des approches méthodologiques construites par le biais de références bibliographiques, interviews, dans la quelle la phénoménologie constitue la base principale aux analyses en question.
\end{abstract}

Mots-clés: Conversion. Identité culturelle. Marqueurs Territoriaux. Wari'.

\title{
Considerações iniciais
}

De família linguística Txapacura, os Oro Wari' possuem uma população estimada em 4.000 pessoas (SIASI/SESAI, 2014) distribuída por 32 aldeias e está subdividida em oito povos: Oro Nao', Oro Eo, Oro At, Oro Mon, Oro Waran, Oro Waran Xijein, Oro Jowin, OroKao'Oro Waji. A autodenominação Wari' que engloba todos esses povos possui como significado "gente", "nós", ou ainda "gente como nós", com o sentido de se distinguir dos demais povos originários da região, assim como em relação à sociedade envolvente.

Esse universo de Wari' encontra-se distribuído em sete terras indígenas da região e ainda outras pessoas dessas etnias em outros municípios rondonienses. O estudo em questão é focado na Terra Indígena Igarapé Laje (TIIL), localizada nas confluências dos rios Guaporé e Mamoré em Rondônia, entre os municípios de Guajará-Mirim e Nova 
Mamoré, numa área 107.321 hectares, a qual abriga uma população estimada em 1100 indígenas (FUNAI, 2017).

O trabalho de campo e a pesquisa foram realizados em agosto de 2017, durante duas semanas, na Aldeia Laje Velho (ALJ) em Guajará-Mirim na TILL (Fig. 1), oportunidade em que dialogamos com os sabedores (anciões e anciãs), lideranças e jovens. Este coletivo faz parte do povo Wari'. A atividade realizada foi um trabalho complementar à disciplina de Geografia Cultural do Programa de Pós-Graduação em Geografia da Universidade Federal de Rondônia/UNIR e coordenado pelo Grupo de Estudos e Pesquisas, Modos de Vida e Culturas Amazônicas - GEPCULTURA.

Neste sentido, propomo-nos investigar o processo de conversão do povo Wari' ao cristianismo através de ações evangelizadoras coordenadas pela Missão Novas Tribos do Brasil - MNTB, que transcreveram parte da Bíblia para a língua originária dos Wari'. Os evangelizadores traduziram, organizaram e confeccionaram cartilhas para uso didático à serem utilizadas nas escolas indígenas.

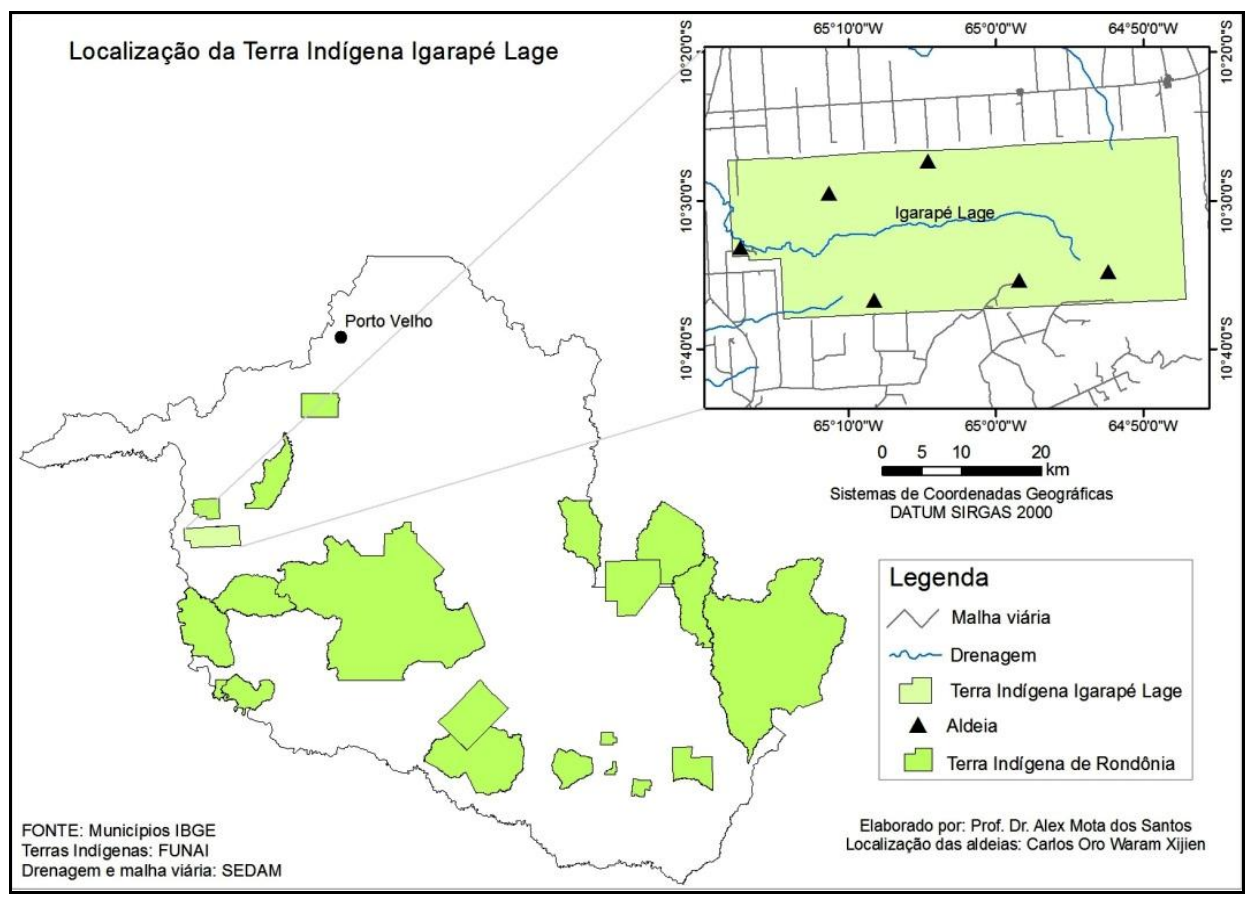

Figura 01: Mapa da TI Igarapé Laje

Fonte: Municípios IBGE. TI FUNAI. Drenagem e malha viária: SEDAM.

O segundo eixo da pesquisa é a identidade cultural desse coletivo, que historicamente teve essa vasta diversidade de valores sociolinguístico-culturais e espirituais, como vítima de ações da sociedade envolvente que fez com que parte 
considerável de suas atividades e etnoconhecimentos fossem ressignificados, cujos resultados são percebidos na espacialidade, como resultado desse processo de aproximação entre culturas distintas.

O último aspecto são os "marcadores territoriais estruturantes e estruturadores", dos quais procuramos estabelecer uma relação dessa temática com as atividades originárias da identidade Wari' e com o processo de conversão cristã desse coletivo em virtude das ações promovidas por influências externas.

Com os três eixos propostos no trabalho (conversão, identidade cultural e marcadores territoriais), faremos o detalhamento em cinco tópicos expostos no desenvolvimento, os quais procurarão demonstrar a relevância dos modos de vida do povo indígena Wari', sob à luz do método fenomenológico abordado por Ernest Cassirer (1992 [1925]; 2001 [1926]; 2004 [1926]; 1953-1957 [1929]; 2005 [1942]; 1968 [1944]; 1978 [1944]; 1994 [1944]; 1976 [1946]; 2005 [1951]; 1975 [1956].

As obras de Cassirer caracterizam-se pela abordagem de que a consciência no campo fenomenológico é marcada pela análise intencional e descritiva da consciência e consideram que as definições quanto às relações essenciais entre atos mentais e mundo externo, ou seja, a verificação no mundo das exterioridades e objetos são identificáveis aspectos imutáveis da percepção dos objetos e a produção de atributos da realidade, com isso permite qualificá-los ou percebê-los ao que realizamos em relação ao mundo. De modo, que o ser e se fazer representar no mundo, é o representar-se e ser representado no mundo.

Os aportes teóricos e metodológicos de Cassirer se concretizam na filosofia da cultura na qual desenvolveu a teoria dos símbolos e formas simbólicas que revelam o fato mítico, estético e social e tem se constituído com relevantes caminhos para discutirmos e abordarmos questões relacionadas à linguagem, mitos, espiritualidade, entre outras conexões interpretativas. Com isso, conceitos como espaço de ação, formas simbólicas, pregnância simbólica, linguagem, substância, formas e função, representações simbólicas.

Sua fenomenologia se dá na perspectiva do espaço-ação, motivada pelas representações e formas simbólicas, nas quais o ser humano está inserido no mundo e está contida na compreensão oferecida pela lógica, relacionada sobre o ser e não sobre o dever ser, em que a compreensão das coisas respalda-se na existência concomitante do real e ideal, caracterizadas como existência fenomenal.

Metodologicamente, os caminhos percorridos em nosso trabalho são alicerçados nos levantamentos de dados realizados durante a pesquisa de campo, tais como, entrevistas, visitas a entidades públicas e não governamentais. Utilizamos a revisão bibliográfica pertinente, bem como participamos de eventos promovidos pela coletividade, o que nos possibilitou melhor compreensão sobre o povo Wari', no que tange seu modo de experienciar o mundo. 
Sobre "A evangelização dos Wari"”, como resultado das primeiras ações missionárias da MNTB, atuação do Serviço de Proteção ao Índio - SPI e o surgimento das epidemias, temos como elemento de análise a contribuição de Vilaça (2007), a qual é uma grande pesquisadora sobre o povo Wari'.

No "Território cultural Wari', procuramos demostrar o vasto domínio histórico desse território pela etnia, seu sufocamento e encurralamento em consequência da exploração do látex por seringalistas e as tradicionais festividades ritualístico-culturais, conforme apontam os estudos realizados por Vilaça (2006).

$\mathrm{Na}$ "Conversão cristã e identidade cultural a análise dessa relação inicia com o estabelecido dos marcadores territoriais" (ALMEIDA SILVA, 2015a) como condição para a compreensão dos fenômenos que produzem repercussões territoriais, sociais, culturais e políticas. Para tanto, a investigação inicia-se com os marcadores estruturadores produzidos pela sociedade envolvente em detrimento às ritualísticas originárias dos Wari', conforme apontam os trabalhos de Almeida Silva (2015a); Vilaça (2006; 2007; 2008; 2017); Conklin (1994); Gallois e Grupioni (1995; 1999).

Em "Algumas características dos marcadores territoriais estruturantes" (ALMEIDA SILVA, 2015a), apresentaremos alguns constructos peculiares da coletividade Wari', tais como, o cosmopolitismo interétnico-feminino, a arte ritualísticaancestral feminina, a mulher mitológica-cosmogônica e a roda de conversa dos anciãos, onde encontramos aporte teórico em Almeida Silva (2015a), bem como nas considerações realizadas por Vilaça (2017) e nas relevantes narrativas de Oro Waran (2017) e Oro Mon (2017).

No último tópico trataremos da "identidade Wari' como marcador territorial estruturante", mediante a especificação de alguns dos marcadores nominados por Almeida Silva (2015a), os quais nos auxiliam na compreensão do modo como esse povo se organiza interna e externamente.

\section{A evangelização dos Wari'}

A MNTB é originária da New Tribe Mission, instituição norte-americana criada no início da década de 1940 que trabalha na evangelização de indígenas através de seus missionários que ao se estabelecerem nas mais diversas etnias, implantam seus templos para atuarem no processo de conversão cristã, além de realizarem a tradução da Bíblia para as línguas desses povos. Deste modo, afirmam Gallois e Grupioni (1995, p. 4) que:

A "New Tribes Mission poderá ilustrar o quanto esse caleidoscópio acerca do que vem a ser 'índio' e 'cultura indígena' representa para esses povos um difícil obstáculo aos seus esforços de diálogo e de intercâmbio com a sociedade envolvente".

Fixados na Amazônia, na porção Sul-Ocidental (fronteira Brasil-Bolívia), esses evangelizadores iniciaram seus primeiros contatos e instalaram-se em Guajará-Mirim em 
fins da década de 1940, até serem reconhecidos oficialmente pelo governo brasileiro em 1953. A partir daí e através do seu primeiro missionário no país, Virgílio Sharp, iniciouse um assíduo processo de conversão cristã com o povo Wari' (CONKLIN, 1994).

A MNTB fortalece suas ações através de intensificada metodologia linguística, em que busca conhecer a língua materna dos indígenas para em seguida fornecer subsídios didáticos, tais como, cartilhas de alfabetização bilíngue e transcrição bíblica para atender esses coletivos. Esses materiais são utilizados, inclusive, nas escolas indígenas.

Destarte, e antes de alcançar esse patamar didático-metodológico, a MNTB precisou adentrar no território Wari' munida de recursos materiais, tais como remédios, com a finalidade de suprir a fragilização do aparelho estatal, na época representado pelo Serviço de Proteção aos Índios - SPI. Essa ação facilitou e contribuiu para que os processos de pacificação e evangelização desse povo, conforme expõe Conklin (1994, p. 162: “Os missionários trouxeram microscópicos para que os Wari' pudessem ver os microrganismos com seus próprios olhos. Também escreveram uma cartilha na língua Wari’ sobre saúde, nutrição e prevenção de doenças”.

Problemática semelhante sobre a fragilidade institucional, a qual propiciou que os missionários se instalassem com facilidade entre os indígenas, por meio da oferta de assistência médica e ao mesmo tempo aprendessem sua língua, é apontada por Vilaça (2007, p. 16):

\begin{abstract}
Diante das precárias condições materiais do SPI (que se perpetuam até hoje na FUNAI) e dada a disponibilidade dos missionários protestantes, que ofereciam recursos materiais e humanos para a empresa da pacificação, estes se tornaram peças-chave no processo de pacificação dos Wari', acompanhando e mesmo organizando as primeiras expedições de contato, nas quais o SPI atuava como coadjuvante.
\end{abstract}

Instalados na aldeia, os missionários passaram a atuar de maneira frequente na área de saúde, de modo que contribuíram no combate às diversas epidemias que acometiam com gravidade os Wari'. Essas ações são reconhecidas como de grande relevância para os Wari', visto que o órgão estatal de proteção aos indígenas não tinha preocupação em atender na saúde, até mesmo em função da própria fragilidade institucional.

Quanto ao processo de evangelização, os missionários atuaram durante toda a década de 1960 e não mediram esforços no sentido de levar os princípios dessa "nova" doutrina cristã aos Wari'. Para tanto, esses evangelizadores organizavam-se em barracas improvisadas no meio da floresta e pregavam as mensagens bíblicas aos "pagãos" que de acordo com suas pregações seriam mais tarde "salvos" por se tornarem convertidos ao cristianismo.

Como resultado desse processo, Vilaça afirma que os Wari' estiveram crentes durante toda a década de 1970 e nos primeiros anos 1980, e esclarece que: "entre 1986 e 
1994, quando realizei as duas primeiras fases de minha pesquisa de campo, havia dois ou mais missionários em praticamente todos os postos da Funai. Mesmo assim, nessa época, os Wari', com raras exceções, diziam-se pagãos" (VILAÇA, 2007, p. 16).

Gradativamente seus modos de vida foram alternados, e os saberes-fazeres ancestrais (etnoconhecimentos) também foram esquecidos ou abandonados no cotidiano Wari', enquanto as práticas religiosas eurocêntricas e judaico-cristã se consolidavam de modo mais intenso na ALV.

É relevante destacar, conforme manifestaram alguns indígenas da ALV, no período em que lá estivemos em 2017 - durante duas semanas ${ }^{1}$ - revelaram que a evangelização trouxe alguns aspectos positivos, em suas avaliações, o processo de paz interna, visto que havia um alto índice de brigas, consumo de bebidas alcoólicas, desunião entre os casais e outros comportamentos considerados prejudiciais a esse coletivo indígena.

Como componente dessa constatação, procuramos estabelecer a conexão com a "ideia de transformação na Amazônia" no contexto da descrição antropológica fundamentada na conversão Wari', e em tal sentido, Vilaça (2008, p. 196) considera que "ao se consubstancializarem com os missionários, e através deles com Deus (que se faz pai), os Wari' vivem uma metamorfose corporal, e passam a experimentar um mundo completamente novo, ou seja, uma nova natureza, embora não uma nova cultura".

Não concordamos em parte com a afirmação da autora ao inferir que não se tratar de uma nova cultura. No nosso entendimento, argumentamos que tal condição nos parece ser inexorável, visto que ao serem inseridos no conjunto da sociedade envolvente, com esta, apreendem novos significados, códigos e representações que hibridiza seus etnoconhecimentos.

Não se pode recusar que embora os indígenas ou povos originários vivenciem o presente, muitas de suas práticas são perpetuamente referenciadas na ancestralidade. De modo, que entendemos três dimensões distinções de temporalidade, a primeira marcada pela relação mítica com a criação do homem e as coisas; a segunda pela ancestralidade com os relatos antes do encontro com a sociedade envolvente; e atual com o encontro ou aproximação com a sociedade envolvente e estendida aos dias atuais, em que essa se ancora também nas temporalidades míticas e de ancestralidades, de jeito que se caracterizam com o que Sahlins (2003, p. 7 e 181 [1985]; 1997a, p. 41-73; 1997b, p. 116) denominam de "mudança e permanência".

Assim, compreendemos que as mudanças e permanências não se dissociam do conceito de cultura elaborado por Hoebel e Frost (2005, p.16 [1976], os quais consideram que a cultura é um fenômeno dinâmico, portadora de uma lógica própria, projeta, a qual constrói e reconstrói o destino dos coletivos não como um processo

\footnotetext{
${ }^{1}$ Apesar do tempo relativamente curto na Terra Indígena Igarapé Laje e na Aldeia Laje Velho, estabelecemos diálogos constantes com Francisco Oro Waram, discente de mestrado no Programa de Pós-Graduação em Geografia da Universidade Federal de Rondônia, durante o período de 2017-2019, o que foi relevante para a construção do presente trabalho.
} 
natural, mas de aquisição de representações com seus significados, representações, sentidos e ressemantizações.

$\mathrm{Na}$ abordagem referente ao processo de evangelização, trata-se de novas significações e representações - ainda que estranhas - as quais foram introduzidas e disseminadas na cotidianidade Wari'. Em consequência, as ações evangelizadoras, apesar de serem vistas como benéficas por considerável parcela do coletivo, trouxe profundas reconfigurações nos originais modos de vida da ALV, inclusive com repercussões na dinâmica territorial e cultural de seu povo.

Essas repercussões propiciaram que ficassem vulneráveis, especialmente no que se refere à fragilidade para a defesa do território, onde a TIIL tem sofrido sucessivas invasões territoriais pelos mais distintos atores sociais (madeireiros, latifundiários, grileiros, pescadores, caçadores, dentre outros). Isso se dá em função de terem abandonado suas armas e não partirem para o confronto como ocorria nos tempos dos seringais nos séculos XIX e XX, conforme narrativas memoriais dos indígenas mais idosos.

Do mesmo modo, a cultura também sofreu importantes modificações, inclusive, no âmbito espiritual, vez que uma série de rituais e festividades não puderam ser mais realizadas, em virtude de tais ações repercutirem negativamente. Tanto a defesa territorial, espiritual, cultural (incluso a questão linguística) e como efeito sobre o meio e a organização social e de parentesco são tidas pelos Wari' da ALV como um sintoma de fraqueza - as ações que faziam no passado, atualmente são tidas como pecaminosas.

\title{
O território cultural Wari'
}

Inicialmente mencionados por Pakaa Nova, devido terem sido avistados primeiramente no rio homônimo, os Wari', além de possuírem uma histórica convivência nos rios Pacaás Novos e Laje, ambos afluentes do rio Mamoré; estendiam seu domínio territorial que acolhia outras rotas, tais como o rio Jaci-Paraná e rio Ribeirão, afluentes do Madeira, conforme contextualizado por Vilaça (2017, p. 44):

\begin{abstract}
Os Pakaa Nova foram mencionados pela primeira vez na literatura em 1870, por Ricardo Franco, que os encontrou na margem direita do rio do mesmo nome (Meireles, 1986: 72). De acordo com Meireles (idem; 121), os Pakaa Nova estavam localizados, por volta de 1840, "nas margens do rio Pacaas Novos e provavelmente - de alguns de seus afluentes, onde permaneceram até 1930.
\end{abstract}

Com o advento dos seringais seu território foi asfixiado, enquanto eram mortos e/ou encurralados, com isso distanciavam-se cada vez mais dos percursos fluviais utilizados pelos colonizadores; a saída foi procurar um maior isolamento no interior da floresta. Por outro lado, as epidemias surgidas durante o contato, principalmente a partir de 1956 dizimaram parte de seus membros (VILAÇA, 2017). 
Os efeitos da sociedade envolvente, apesar de sua extrema violência, não foram suficientes para provocar seu extermínio, assim sobrevivem com sua bravia resistência a uma caótica e negligente política indígena estatal e as sequelas de demais fatores externos que tem provocado um genocídio histórico e promove ações persuasivas, marcado pelo etnocídio; um exemplo desse cenário é o crime de se querer exterminar seus valores culturais, sociais, espirituais, bem como a ocupação ilegal e expropriação das riquezas naturais presentes no seu território, dentre outros fatores que impactam o modo de vida. Essas constatações são pormenorizadas na descrição de Almeida Silva (2007; 2012; 2015b), em que o autor apresenta eventos que rotineiramente ocorrem em Rondônia.

Durante nossa pesquisa na ALV, constatamos por meio das entrevistas com os Wari' que há uma predominância de valores evangélicos que foram implantados na comunidade, com isso se percebe que uma grande parcela da população se dedica à uma rígida dedicação aos estudos bíblicos, ao mesmo tempo em que ocorre um acentuado apagamento das práticas culturais originárias daquele coletivo.

A identidade Wari' e sua territorialidade estão ancestralmente imbricadas em seus valores simbólico-cosmogônicos. Para Cassirer (1978, p. 50 [1944]), "O homem já não vive num universo puramente físico, mas num universo simbólico". Neste sentido, Francisco Oro Waran (2017), pertencente ao povo Wari' e morador da ALV explica como ocorreu a gênese de seu povo:

A caverna deles era uma gruta com uma entrada estreita, os pais como eram muito gordos, não puderam sair, ficaram presos na gruta e então gritaram: - Suas mulheres vão ficar pequenas e não vão passar de suas cinturas, é por isso hoje que as mulheres são menores do que os homens. As filhas tiveram filhos, netos e bisnetos, e assim foi o surgimento dos subgrupos Oro Wari'.

São justamente essas peculiaridades que mantêm, fortalecem e dinamizam esses relevantes aspectos da rica diversidade cultural material e imaterial que devem permanecer impregnados no imaginário social e simbólico desse espaço vivido. "É vivido não em sua positividade, mas com todas as parcialidades da imaginação". (BACHELARD, 1989, p. 19).

Neste sentido, tratam-se de valores entrelaçados a seus modos de vida e herdados de seus antecedentes que os Wari' compreendem que precisam ser resgatados, são saberes-viveres presentes na simbologia xamânica, nas narrativas cosmogônicas, nos relatos memoriais sobre a antropofagia funerária e as brigas de bordunas, e no retorno aos festivo-ritualísticos como a Tamara, a Huroin e Hwitop (VILAÇA, 2006).

Essas festas são relevantes atividades ritualística-culturais, necessárias à organização interna dos Wari', ao fortalecimento da identidade e a proteção vigilante do seu território, visto que através dessas atividades, os subgrupos Wari' estabeleciam interligações por clareiras abertas na mata, fator que possibilitava a identificação da 
presença de algum inimigo no seu território. Para esclarecer alguns aspectos, elementos e fenômenos das festividades ritualísticas desse povo, Vilaça (2006, p. 118) considera que:

O huroroin' é a festa mais complexa das três, pois envolve uma diferenciação de gêneros interna ao grupo dos convidados e ao grupo dos anfitriões. Até possivelmente o início dos anos 1900, ou um pouco depois, essa festa se realizava entre os diversos subgrupos.

A festividade mencionada pela autora é caracterizada por rituais de danças, bebidas como a chicha, comidas, músicas, aberturas de clareiras na mata, pinturas corporais, tambores, flautas e demais simbologias que constituem a organização social Wari', alicerçada à natureza espiritual.

Para além dessas qualificações, entendemos que do ponto de análise geográfica - mas não exclusivamente por ela -, essas atividades servem para fortalecer os laços de parentesco, de vizinhança, visto a existência da relação com a natureza, além de proteção territorial e se constituem como importantes marcas identitárias, aqui denominadas de marcadores territoriais estruturantes, pois são considerados constructos da coletividade, diferentemente dos marcadores estruturadores, que são ações procedentes da sociedade envolvente (ALMEIDA SILVA, 2015a).

\section{Conversão cristã e identidade cultural: relação com os marcadores territoriais}

Neste tópico, utilizamos o aporte teórico de Almeida Silva (2010; 2015a) para definir os marcadores territoriais e demarcadores territoriais. O primeiro conceito é caracterizado como estruturantes e o segundo como estruturadores. Para o autor (2010, p.105), marcador territorial tem a seguinte definição.

A concepção de "marcadores territoriais" pode ser compreendida a partir dos símbolos que ocorrem enquanto espaço de ação, definem territorialidades vinculadas à cosmogonia e experiências socioespaciais e possibilitam a formação das identidades culturais e do pertencimento identitário. [...] são experiências, vivências, sentidos, sentimentos, percepções, espiritualidade, significados, formas, representações simbólicas e presentificações que permitem a qualificação do espaço e do território como dimensão das relações do espaço de ação, imbricados de conteúdos geográficos.

O segundo conceito é descrito por Almeida Silva (2010, p.116-117) como aqueles que "estão relacionados a um processo da sociedade envolvente e ocorre por imposição jurídica, ou seja, de fora para dentro do espaço, como afirmação das políticas territoriais do Estado". Deste modo, muitas vezes não se considera o legado cultural e a ancestralidade coletiva daqueles que habitam suas territorialidades desde tempos imemoriais. O autor considera que para além do Estado existe ainda as influências e interferências externas que são inseridas por diversos atores sociais no meio das populações indígenas ou originárias e povos tradicionais. 
$\mathrm{O}$ autor define os marcadores estruturantes como aqueles que são promovidos internamente pela coletividade e encontra-se relacionados à uma territorialidade composta pela cosmogonia e pela relevância de suas simbologias, o que se caracteriza como base fenomenológica. Os marcadores estruturadores ou "demarcadores territoriais", por sua vez, na proposição do autor, refere a fatores externos, os quais exercem influências na coletividade e que resultam na alteração de seus modos de vida. Neste sentido podemos dizer que o processo de conversão cristã Wari' é um "estruturador", enquanto sua identidade cultural é um "estruturante".

Entendemos que não se trata de um dualismo ou polaridade dualística, visto que se alude a situações de temporalidade e territorialidade que são construídas em momentos específicos da trajetória da coletividade. Essas condições não implicam em afirmar que uma é superior a outra, mas que na situação vivenciada pelos Wari' remete à concepção de hibridismo. Neste sentido, as expressões dos indígenas consideram que existe uma complementaridade, isto é, o contato não trouxe apenas "coisas" ruins, mas também apresenta virtudes - para tanto, colocam a saúde e a educação como algo que tem possibilitado o acesso daquilo que não possuíam antes do contato - de modo que apreenderam e aprenderam códigos, significados e representações que permitem dialogar com a sociedade abrangente.

As concepções de marcadores territoriais defendidas por Almeida Silva (2010; 2015a) aproximam-se sob certos aspectos ao que Pacheco de Oliveira (2019) considera como "situações de fronteira", aqui compreendida como um instrumento de análise que relaciona menos ao espaço geográfico, e sim a uma situação presente nas relações entre povos, uma territorialidade, onde se constituem modos de dominação e exploração, inclusive simbólica.

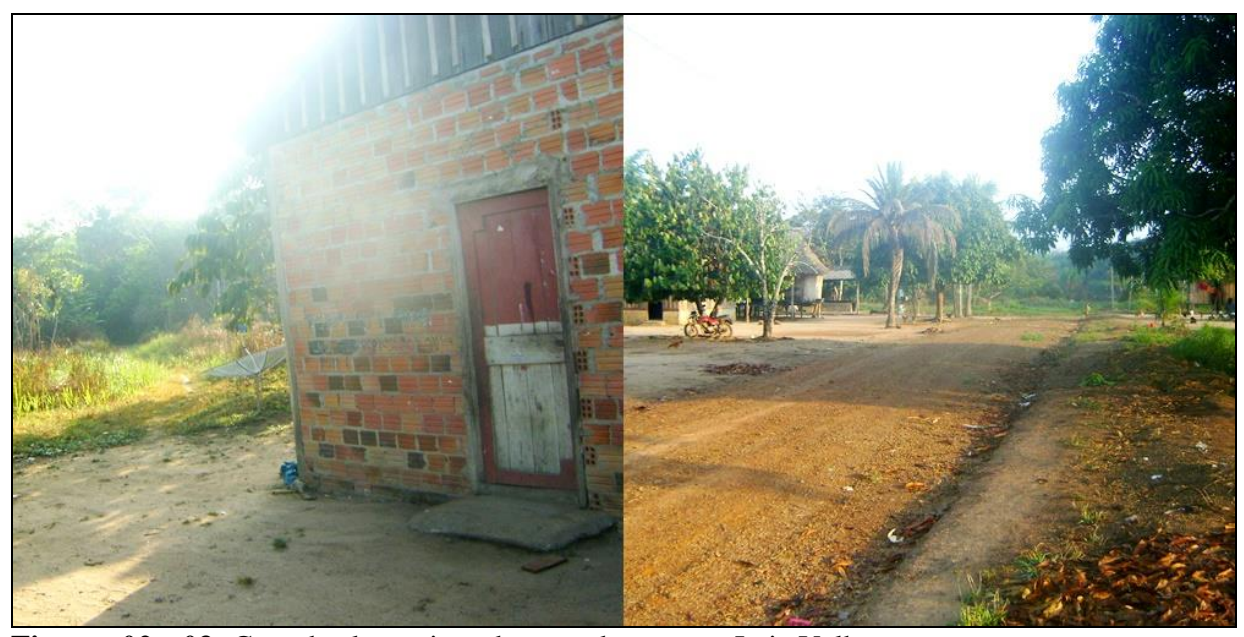

Figuras 02 e 03: Casa de alvenaria e abertura de ruas em Laje Velho.

Fonte: GEPCULTURA (2017). 
As construções de casas de alvenaria e a abertura de ruas na ALJ, são, por exemplo, aspectos de marcadores estruturadores, visto que não fazem parte dos modos de vida tradicionais deste povo, e sim da sociedade envolvente (Figuras 02 e 03), como são os casos tipificados e demonstrado nas figuras, as quais foram inseridas após o contato e aproximação com o não indígena.

Assim, descrevemos algumas características de "marcadores territoriais estruturadores", antes de tratarmos especificamente da temática da conversão cristã Wari'. Apresentamos por meio de imagens alguns aspectos relacionados a esses "marcadores" identificados na pesquisa. As imagens e as relações estabelecidas com os modos de vida ancestrais originários, não se configuram que somos a favor ou contra os divergentes tipos de lazeres, mas sim, respeitar as decisões tomadas pelo coletivo. Desta maneira:

O que se questiona, entretanto, não é a manutenção tradicionalista de uma "cultura do passado", mas a necessidade da cultura amazônica, como expressão de um presente histórico, manter-se como processo, procedendo suas trocas simbólicas com outras culturas, sem mutilações ou substituição, permanecendo respeitada e integra no ethos ético-estético que constitui. (LOUREIRO, 2001, p. 404).

Realizamos um paralelo com as antigas moradias Wari', em que o número de casas de uma aldeia de roça era bastante variável. Algumas delas tinham apenas duas casas, enquanto outras chegavam a nove (VILAÇA, 2006, p. 71). O que atualmente é considerado um "marcador estruturador", antigamente era um "estruturante".

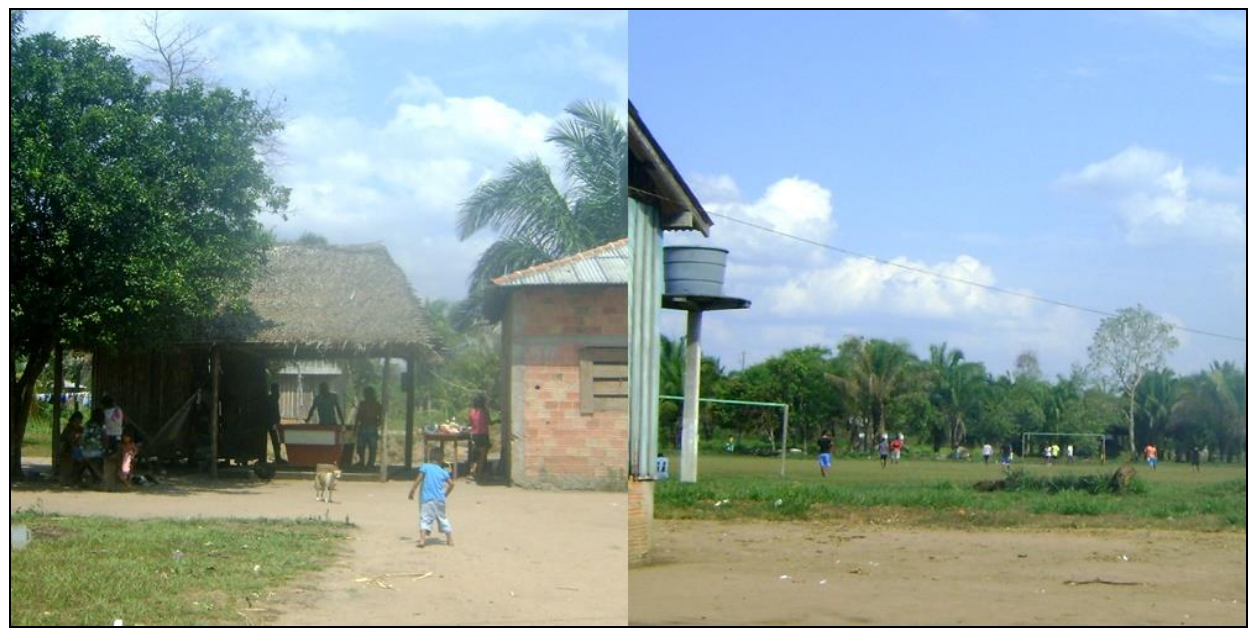

Figuras 04 e 05: Jogos de bilhar e futebol em Laje Velho.

Fonte: GEPCULTURA (2017). 
Apresentamos dois exemplos de atividades de lazer utilizadas na ALV e considerados "marcadores estruturadores". São os jogos de bilhar e futebol (Figuras 04 e 05), em que esses substituíram ao longo do tempo e por influências externas, as festividades ritualísticas como a Tamara, o Huroin e o Wytop', de acordo com os relatos dos Wari' e confirmado por Vilaça (2006).

Outra comemoração extinta - que compreendemos que era de forte impacto e abolida, por influência missionária, a qual tem como princípio que tal ação é contrária aos valores religiosos exercidos nas sociedades ocidentais - era originária das vitórias conquistadas sobre povos rivais, em que o crânio do guerreiro inimigo (wijam) era tido como um trunfo, conforme destaca Vilaça (2017, p. 125):

O crânio era, muitas vezes, guardado como troféu. Amarravam-se os maxilares e pintava-se o conjunto com urucum. Depois, era pendurado em uma casa. Algumas vezes, moradores de outras aldeias chegavam para apreciar o troféu. Segundo alguns, os Wari' costumavam usar esses crânios como gaiola de passarinhos.

Outras características ligadas aos "marcadores estruturadores" são os meios de comunicação atuais como as antenas de televisão e de telefonia móvel. (Figuras 06 e 07). Essas tecnologias são consequências da relação do coletivo com a sociedade envolvente. São exemplos de marcadores presentes no cotidiano Wari'.

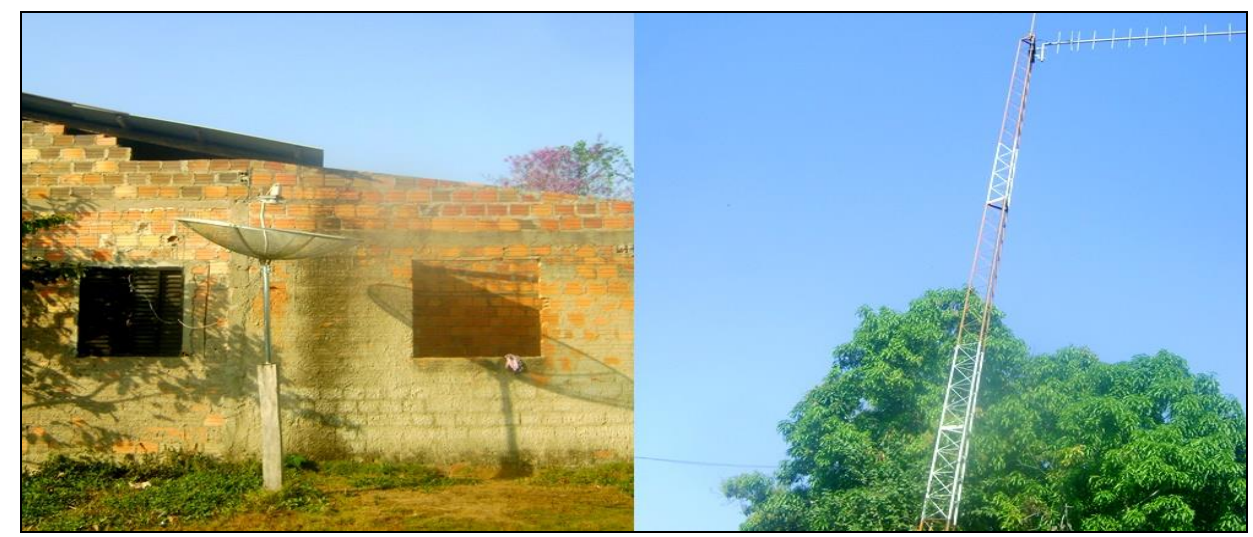

Figuras 06 e 07: Antena parabólica e telefonia móvel em Laje Velho. Fonte: GEPCULTURA (2017).

Essas tecnologias, como parte do processo de relação com a sociedade envolvente, substituíram o uso de rios e fumaças considerados importantes meios de comunicação para os povos originários e se constituem como instrumentos que permitem se interconectar com o mundo, de modo, que facilitam na realização de denúncias contra o território e o povo, além de atender outras necessidades do coletivo. 
Na compreensão dos Wari', seus antepassados eram habilidosos guerreiros, os quais procuravam encontrar estratégias de defesa que os colocassem em posição de segurança. Buscavam se distanciar das rotas fluviais para que não fossem identificados com facilidade pelos colonizadores e povos rivais. Com isso trabalhavam incansavelmente, abriam extensas clareiras no interior da floresta, as quais serviam dentre outras finalidades, de meios de comunicação entre os povos que compõem o microcosmo Wari'.

Eram por meio dessas clareiras que se comunicavam para organizarem encontros festivos e ritualísticos, o que proporcionavam que seus contatos fossem mais frequentes e evitavam assim o distanciamento dos demais coletivos indígenas regionais. Nas clareiras eles também armazenavam "peixes moqueados, pamonha, chicha doce, mel e também farinha de mandioca” (VILAÇA, 2017, p. 178).

O notável é que através de uma comunicação ancestral como essa, surgiu outro importante objeto, o assovio, considerado essencial à integração dos coletivos Wari'. Eles aconteciam principalmente no meio das clareiras, durante os intervalos das viagens, assim como da aproximação da realização das festividades ritualísticas; serviam para anunciar o encontro entre os convidados e anfitriões da aldeia. Essa importância é destacada por Selma Oro Nao:

Enquanto se organiza a festa, os visitantes que estão no acampamento mandam quatro rapazes para avisar a comunidade na aldeia. Eles não entram na aldeia, eles assoviam três ou quatro vezes e voltam para os seus grupos no acampamento. Na aldeia quando sabem que os visitantes estão chegando, cada pessoa tem que levar a comida para o visitante. Então os visitantes dançam e cantam para receber o povo, e recebem a comida, eles ficam três dias na mata. Depois vão entrar na aldeia e começar a cantar até amanhecer. (ORO NAO, 2016, p. 11).

As clareiras e os assovios são considerados importantes "marcadores estruturantes", pois integram o conhecimento ancestral do povo, visto que trata-se de códigos e representações de linguagem apreendidas e vivenciadas por eles.

Além das características mencionadas anteriormente situaremos a seguir mais um aspecto de "marcador estruturador" identificado durante a pesquisa; trata-se da utilização de aparelhamento de som e instrumentos musicais eletrônicos introduzidos na aldeia devido à influência externa. Esses substituíram no espaço e tempo os instrumentos ancestrais como as flautas e tambores utilizados nas festas ritualísticas da Tamara, Huroin e Hwitop', realizadas pelos Wari'.

As três festas ritualísticas estão entrelaçadas à simbologia artística, visto que Tamara "é o nome da música, caracteristicamente masculina cantada nessa festa" (VILAÇA, 2017, p. 180); Huroin "é uma flauta comprida de bambu que mede cerca de dois metros, com uma pequena cabaça na ponta" (p. 190); o Hwitop acontecia "no final 
da festa, nesse mesmo primeiro dia, os anfitriões dançavam Hwitop em linha, soprando pequenas flautas e tocando o tambor por um pequeno período" (p. 199).

Enquanto os jovens Wari' cantavam, tocavam e se divertiam com suas modernas aparelhagens de som. Indagamos à uma jovem indígena qual música cantava, e assim respondeu: "Xiri nain tamatrakon iri yiam na timixi" (nosso coração é a casa do Senhor). Em seguida outra jovem entoou uma canção, cujo título era "Kair xima Ken win mó ne. Auri na pain ka' houva mon iri yam". (Sem Deus você não é nada. Você tem que acreditar e louvar a Deus).

As consequências do contato propiciaram que suas atividades culturais ancestrais passassem por transformações e que várias dessas práticas tornassem-se extintas, esquecidas, não mais realizadas ou ainda hibridizadas, conforme esclarece Canclini $(2008$, p.29) o qual afirma que essas apresentam maleabilidades em "[...] nomear não só as combinações de elementos étnicos ou religiosos, mas também a de produtos das tecnologias avançadas e processos sociais modernos ou pós-modernos".

Parece não ser mais possível reproduzir antigas práticas inerentes aos seus modos de vida, de maneira integral. "Novas" canções e composições musicais de inspiração bíblica surgiram com o advento da evangelização protestante que culminou posteriormente no aparecimento da conversão cristã, e é sobre este "marcador estruturador" que trataremos a seguir.

Partimos da afirmação que o processo de conversão nesses coletivos é um "marcador territorial estruturador", visto que se refere à "[...] inserção de segmentos religiosos estranhos à cosmogonia, a inserção de línguas, entre outros fatores constituem importantes elementos desses marcadores" (ALMEIDA SILVA, 2015a, p. 108).

Esses elementos introduzidos pela MNTB no território Wari' com a aplicação de ensinamentos do protestantismo, fez com que preceitos cristãos adquirissem considerável aceitação. A intensificação e propagação dos ensinamentos bíblicos trouxeram-lhe uma visão ocidentalizada (europeia, judaico-cristã) baseada em novos princípios morais para o estabelecimento de mudanças em suas relações sociais, culturais, espirituais, dentre outras, e oferecem um "sucesso" pessoal e familiar em sua coletividade.

Neste sentido, a conversão ao evangelho levaria prosperidade a suas vidas, e a superação de problemas como desavenças familiares, atrito entre os parentes e o consumo de bebidas alcoólicas, dentre outros comportamentos "ofensivos" à fé cristã e consideradas produtoras de pecado.

$\mathrm{Na}$ abordagem de Vilaça é constatado que tiveram dificuldades em aceitar esse Deus criador, do qual falavam os missionários no início da catequese, mas que facilmente aceitaram como prática cristã, visto que "pareciam ter em sua cosmologia um espaço para esse Deus criador, que aconteceu aí não um encontro de cosmologias, mas sim de sociologias" (VILAÇA, 2007, p. 18). 
Neste caso, a autora analisa este "encontro de sociologias", dentro de sua visão, que a adoção cristã não interrompeu o interesse do coletivo de encontrar-se na constante busca pela "captura do outro", em razão que "o interesse pelo cristianismo esteve desde sempre fundamentado em um problema interno à cultura Wari"” (VILAÇA, 2008, p. 194).

Ressalta-se que apesar da "aparente" aceitação ao protestantismo por acentuada parcela dos Wari' não caracterizou-se o processo de conversão algo estável. Tanto poderá aumentar, como poderá haver redução significativa de seus "fiéis" por esse meio de "salvação".

De certa maneira haverá continuidade nesse processo, mesmo que em alguns aspectos, existam rupturas no espaço e tempo, mas ocorrerá dinamismo na relação cultural originária e a sociedade envolvente, e constitui-se como hibridização ou novas representações. Ao estudar o 'sistema médico Wari', Conklin (1994, p. 169-170) apresenta:

Em 1969-1970, grande parte dos Wari' passou por uma ampla, ainda que breve, conversão ao cristianismo sob a influência da Missão Novas Tribos, que tentou persuadi-los a abolir o xamanismo de suas práticas. Desde o final dos anos 70, no entanto, tem sido observado o ressurgimento desta prática em quatro das maiores aldeias: Rio Negro-Ocaia, Santo André, Laje e Ribeirão. Em parte, isto reflete a flexibilidade da cultura Wari' e o renascimento recente do interesse por suas tradições, em especial determinadas cerimônias, música e dança.

Desta maneira, a constatação apresentada é revisitada por Almeida Silva (2015a, p.108) ao expor que "tais fatos, consequentemente metamorfoseiam o modo de vida e da própria coletividade, o que resulta em novas apreensões de representações e figuras simbólicas".

Concordamos com o autor, e esclarecemos que não nos reportamos, exclusivamente à conversão cristã, mas a todos os aspectos de "marcadores estruturadores" citados anteriormente. Porém, é importante enfatizar que os ensinamentos procedentes das práticas ocidentais cristãs de certo modo se sobrepõem às práticas culturais indígenas.

Durante nossa pesquisa na ALV, tivemos a oportunidade de conhecer a programação dominical desenvolvida pela MNTB. As tarefas de evangelização eram organizadas de acordo com a faixa etária dos indígenas. Três cultos dominicais foram realizados naquele dia. $\mathrm{Na}$ igreja foi realizado um culto para adultos e era conduzido por pastor indígena.

Geralmente a formação de pastores passa por uma série de recomendações fundamentadas a partir da fidelidade à doutrina religiosa, o que exige gradativamente requisitos destinados à assimilação de preceitos que fortaleça a difusão e pregação eficiente do discurso cristão. Nos anexos existentes próximos à igreja foram realizados 
distintamente, o culto para as crianças (Figura 08) que era coordenado por uma jovem Wari' (Fig. 9); o direcionado aos jovens a pregação era de responsabilidade da missionária da MNTB.

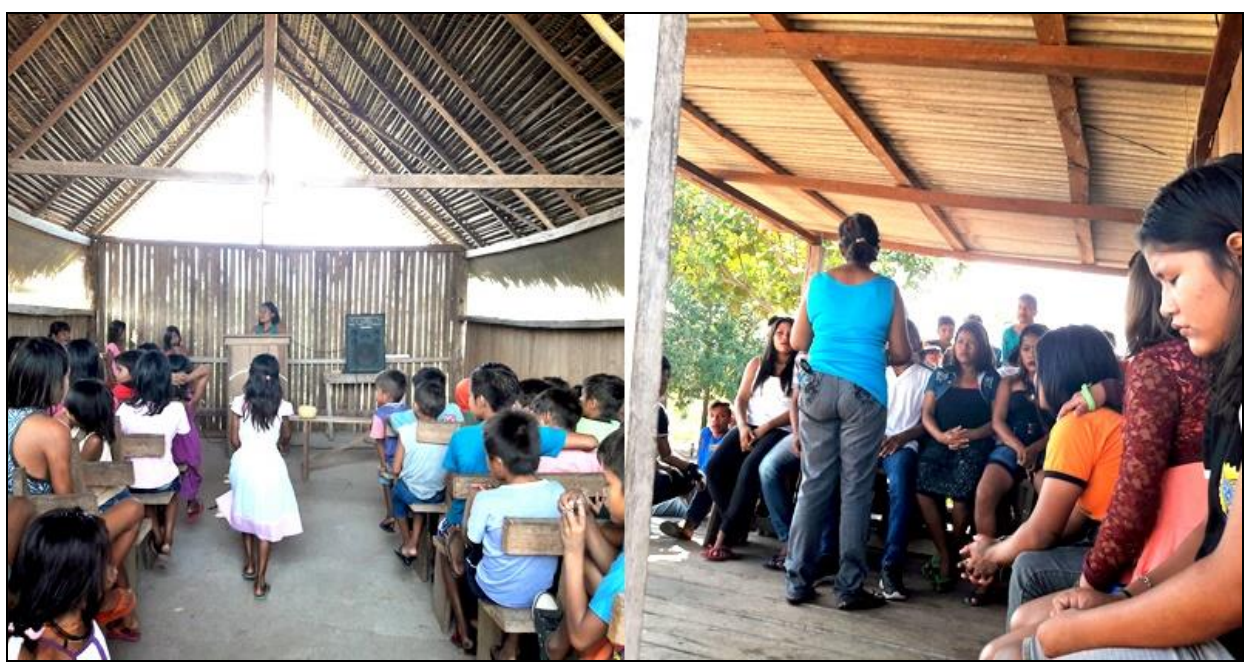

Figuras 08 e 09: Culto dominical para crianças e jovens em Laje Velho.

Fonte: GEPCULTURA (2017).

As atividades evangelizadoras nesses coletivos partem principalmente da premissa com a predominância do aspecto religioso-assistencialista destinadas especialmente à educação e aos estudos bíblicos.

Este desenvolver se situa no "contexto da insuficiência da assistência leiga oficial e da violência nas relações que a população envolvente mantém com os índios, os missionários se tornam rapidamente um apoio julgado indispensável pelos povos alcançados" (GALLOIS; GRUPIONI, 1995, p. 47).

Estes autores destacam ainda a atuação das missões e ressaltam que essas partem do campo institucional e ideológico que continua a propor no campo indigenista, atribuições de humanidade aos povos originários, por meio da difusão de uma igualdade que necessariamente destrói os particularismos indígenas e justificam remodelar essas culturas em função da concepção unilinear de evolução. Para tanto, estabelecem a crítica que:

É nesse campo amplo de disputas ideológicas e não no micro debate entre missionários e "defensores da perpetuação da cultura", que deveriam ser avaliados os impactos do universalismo entre os índios. A continuidade desta indagação deverá partir do ponto de vista dos nativos, para verificar se estes povos conseguem assumir a igualdade proposta pelos missionários sem aceitar, ao mesmo 
tempo, a inviabilidade de suas especificidades culturais. (GALLOIS; GRUPIONI, 1995, p. 52).

Percepção semelhante é encontrada em Vilaça, a qual esclarece que entre 1986 e 1994, havia missionários entre os Wari', e que estes com raras exceções, diziam-se pagãos. Posteriormente a autora afirma que em "2002, quando retornei a pesquisa de campo, encontrei grande parte das pessoas dizendo-se crentes, e hoje há cerca de oito missionários não-indígenas vivendo com eles. Na maioria, os cultos são conduzidos por pastores nativos" (VILAÇA, 2007, p. 16).

Notadamente entre eles o cristianismo surgiu como relevante suporte no sentido de contribuir para a diminuição de "atos pecaminosos", procedentes ou não, da sociedade envolvente. Nessa "busca pelo outro" (VILAÇA, 2008, p. 196), afirma que: "O cristianismo é para eles, ao menos nesse momento, antes de tudo uma nova perspectiva sobre as relações, instituída por um ato criador de origem inimiga".

A propósito, a demonstração da relevância de análise dos "marcadores estruturadores" na temática de estudo sobre a cultura indígena e a sociedade envolvente, propicia que "na esmagadora maioria das ocasiões não pondera sobre os divíduos ${ }^{2} \mathrm{e}$ coletividades, não considera a anterioridade e atuam como propagadores de rupturas dessas identidades". (ALMEIDA SILVA, 2015a, p.107).

\section{Algumas características de "marcadores territoriais estruturantes"}

Os "marcadores estruturantes" compartilham a ideia de construção a partir da visão dos divíduos de determinada coletividade e envolve os aspectos fundantes da cosmogonia (ALMEIDA SILVA, 2010; 2015a). No entrelaçamento deste conceito procuramos detectar algumas características desses marcadores que demonstrassem possuir relação com os valores culturais dos Wari'.

O primeiro item analisado é o que chamamos de "cosmopolitismo interétnicofeminino" que está estritamente relacionado à força e união das mulheres indígenas (Fig. 10), durante encontro de grande relevância para o fortalecimento da luta protagonizada pelas Wari', inclusive que culminou com a feira cultural de arte ritualística-ancestral feminina (Fig. 11).

O encontro foi coordenado por Leonice Tupari, presidente da Associação das Guerreiras Indígenas de Rondônia - AGIR, entidade que busca construir importante rede de formação, organização e articulação com vista a contribuir para a autonomia e empoderamento dessas coletividades.

\footnotetext{
${ }^{2}$ Esse conceito reflete a noção de corpo e pessoa entre os melanésios, o qual é caracterizado por Strathern (2006, p. 40-41) "as pessoas são frequentemente construídas como o lócus plural e compósito das relações que a produzem".
} 


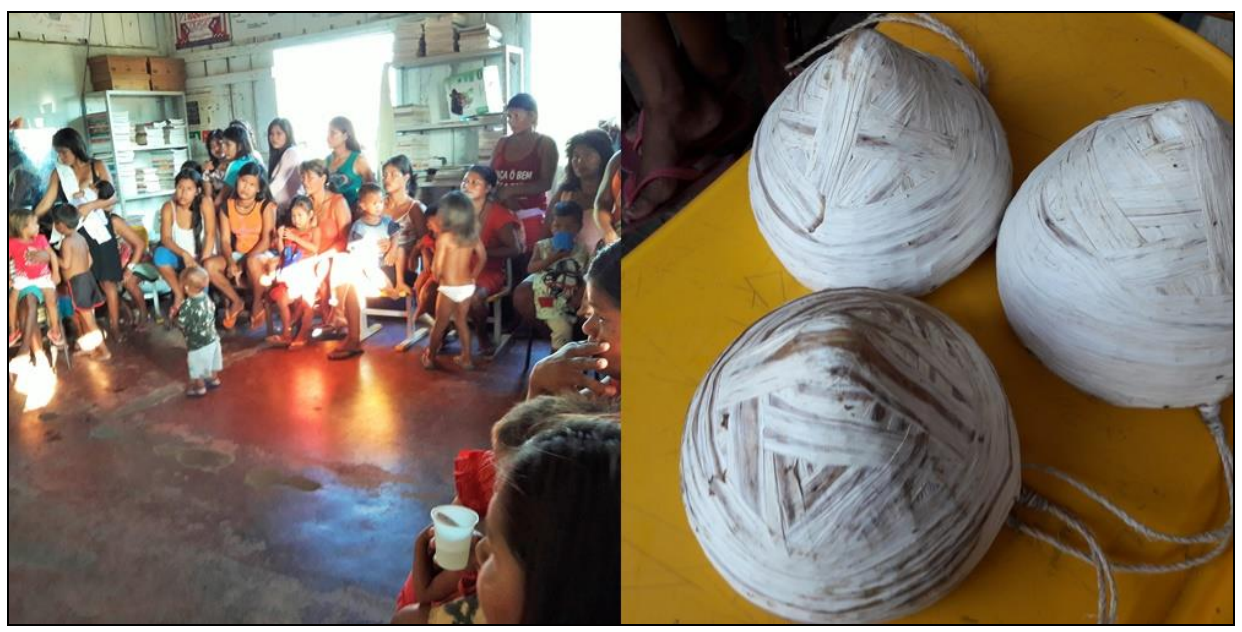

Figuras 10 e 11: Mulheres Wari' e Tambor (Towa) feminino em Laje Velho. Fonte: GEPCULTURA (2017).

Outra importante liderança rondoniense, Gasodá Suruí, presente no encontro e em entrevista em 2017, nos falou sobre a importância da luta e organização das indígenas:

\begin{abstract}
A Leonice Tupari é uma guerreira, é uma liderança. Ela motiva as mulheres a lutarem pelos seus direitos. Essa luta é muito importante, porque precisamos hoje no Estado, de um movimento indígena que corresponda a altura de todas as comunidades, para que só assim, a gente possa garantir um futuro melhor para nossas comunidades, sejam homens, mulheres, jovens, crianças. Tudo isso, a luta das mulheres fortalece o nosso movimento como um todo. A AGIR é uma organização indígena voltada para as mulheres e tem três anos de existência e o que está acontecendo hoje aqui, pra mim é uma coisa inédita, porque nenhum movimento indígena chegou a esta base como o que tem acontecido com as mulheres. Esse movimento tem buscado essas mulheres dentro das comunidades, dentro de suas aldeias, pra poder articular com elas sobre o momento que nós estamos vivendo diante do descaso dos governantes do nosso país para com os povos indígenas.
\end{abstract}

A luta dessas mulheres é uma realidade emergente de visão eminentemente cosmopolita, pois promove articulação singular e plural dessas guerreiras na incansável luta pela conquista de seus direitos individuais e coletivos, pois realiza a interlocução entre a aldeia e o mundo urbano, para além dos limites regionais e nacionais.

Com isso, por meio da organização estabelece contatos, acordos, convênios e cooperações com distintos atores sociais, instituições públicas e não governamentais, exigem o estabelecimento e o cumprimento de políticas públicas, de modo que se 
presentificam e constroem narrativas para consolidação do protagonismo a partir de suas necessidades prementes.

O segundo identificado e relacionado aos "marcadores estruturantes" foi a "arte ritualística-ancestral feminina" apresentada durante feira cultural em ALV. Neste cenário artístico-cultural indígena foi exposto, além de diversas peças artesanais, o tradicional tambor feminino de caucho (towa), ancestral simbologia que esteve presente nas ritualísticas e festividades dos Wari'.

Desde tempos imemoriais os towa eram utilizadas nos rituais e festividades dos Wari' e variavam de tamanho conforme as especificações de exibição das ritualísticas. Em conformidade com Vilaça (2017), o towa era feito de uma panela cônica de argila (tapaxi') e constituía-se como trabalho feminino e competia aos homens recobri-lo com tiras de caucho.

O tambor era tocado com o auxílio de vareta coberta com linha de algodão tingida de urucum; tem na parte superior uma alça, a qual serve para pendurá-lo no ombro do tocador. Durante a festa denominada Huroroin', o towa era utilizado pelas indígenas:

As mulheres convidadas, sentadas em linha na clareira, cantam ao som de um pequeno tambor de caucho, towa (miniatura daquele que se toca no tamara), as ijain jê e', canções femininas. A voz é fina, agudíssima. A batida do towa feminino, ritmada, é mais rápida que aquela do tamara. A melodia é única - e diferente do tamara - e as letras parecem constituir um repertório finito, de origem ancestral, preservado na memória das mulheres (VILAÇA, 2017, p. 194).

Essas práticas de rituais entre os gêneros é um modo evidente da importância da mulher na construção dos modos de vida de seu povo. O towa feminino é apenas uma das grandes demonstrações de luta e resistência das Wari'. Ele permanece vivo em seus rituais e constitui-se peculiar simbologia de uma ancestral história de vida construída e desenvolvida no espaço e tempo desse coletivo que conseguiu sobreviver às mais diversas situações de pressões e ameaças.

Na ALV visitamos a Escola Indígena Won Kanum Oro Waran e tivemos a oportunidade de presenciar uma atividade desenvolvida por estudantes e organizada por Francisco Oro Waran - uma das lideranças Wari' e na época discente de mestrado do PPGG/UNIR. A atividade tratava da "mulher mitológica-cosmogônica" como terceira característica dos "marcadores estruturantes" identificada nessa coletividade.

Entendemos que esses valores culturais estão relacionados à cosmogonia, indissociáveis de uma ancestral axiologia mitológica. Considerada imprescindível ao resgate da identidade coletiva, a atividade foi desenvolvida através de encenação teatral que revelou a criação mitológica dos Wari', que ocorreu depois de grande inundação na terra, conforme Francisco Oro Waran (2017): 
Nossos pais contavam que naquele momento começou a chover. Chovia dia e noite sem parar, os dias passavam, passavam e a chuva continuava. Os rios saíram do seu leito e invadiu a terra firme. Alagaram os caminhos, as casas e os roçados. Uma velha caminhava debaixo da chuva com um paneiro ${ }^{3}$ nas costas, era o espírito da chuva e a dona da chuva. Ela aproximou-se de uma aldeia, fingindo que ia passando, os Wari' chamaram: - Vem cá vó! Venha se aquecer no fogo. Ela sentou próximo ao fogo, depois entrou numa casa, ajeitou suas roupas, se despediu e disse: - Já vou meninos. - Espere vó. Disseram eles. - Não, eu tenho que ir. Eu vou embora. Disse ela. Começou novamente a chover mais forte e subiu todos os peixes, era matrinchã, surubim, cará, mandi, tucunaré. Os Wari' flecharam muitos peixes e a chuva continuava a cair, não se via nem o mato nem a terra, só se via água, era água por todo canto. Um homem apareceu e avisou aos meninos, ele foi embora e chamou os parentes, que estavam mais preocupados em flechar os peixes, eles não quiseram ir. A esposa dele concordou em ir embora com ele e o casal saiu da aldeia, subiram num paiol de milho e se acomodaram. Pela madrugada eles ouviram um grande barulho, era a terra que afundou de uma vez. O pai pensou que os seus parentes devia ter morrido, e chorou, chorou até amanhecer o dia, depois foi reparar a aldeia, e nem encontrou nenhuma casa e nem gente, os parentes tinham se transformado em passarinhos e em jacaré. Eles choraram muito e passaram dois anos numa grande tristeza, no terceiro ano o homem que só tinha filhas disse para a esposa: - Vou atrás de gente. Ele saiu devagarzinho e foi, procurando rastros, mais voltou muito triste sem encontrar. No dia seguinte ele foi de novo, naquele momento ele encontrou os rastros do povo Oro Wari'. Voltou novamente com as filhas pequenas para o mato, quando viu umas mulheres apanhando mamão. O homem se aproximou delas e contou para uma das moças que os parentes dele tinham morrido numa grande alagação. Ele perguntou se elas, as moças, tinha pais e irmãos, pois queria conversar com eles. Então ela levou ele até onde eles moravam. Eles moravam numa caverna de pedra. Morava uma família nessa caverna. Então o homem ofereceu suas filhas para se casarem. Saíam depressa da caverna, casem com minhas filhas para que vocês possam se multiplicar. E assim os homens vão saindo da caverna. Então assim vão casando as meninas. Os pais dos meninos não conseguiram sair da caverna, devido os corpos deles serem muito grande. Então o pai dos meninos falou, ele disse o seguinte: Vocês vão se multiplicar, vocês vão crescer muito e um dia vocês vão morrer, e as esposas de vocês também. A caverna deles era uma gruta com uma entrada estreita, os pais como eram muito gordos, não puderam sair, ficaram presos na gruta e então gritaram: - Suas mulheres vão ficar pequenas e não vão passar de suas

${ }^{3}$ Termo regional amazônico para um cesto feito de fibras vegetais e utilizado para guardar, transportar, enfeitar, dentre outras funções. De modo interpretativo, guarda semelhanças com balaios e/ou cestos de colocar roupa. 
cinturas, é por isso hoje que as mulheres são menores do que os homens. As filhas tiveram filhos, netos e bisnetos, e assim foi o surgimento dos subgrupos Oro Wari'.

Momentos singulares como essa narrativa se fundem na pluralidade espíritonatureza, uma multiplicidade de valores entrelaçadas na vastidão de suas simbologias e coloca a mulher Wari' como protagonista de sua própria criação.

A quarta característica mencionada aqui como "marcador estruturante" é a "Roda de conversa dos anciãos". Neste encontro de gerações, os anciãos demonstram a preocupação com a vida e com a natureza. Os relatos nos leva à compreensão de fatores que perpassam da organização político-social do território às dimensões culturalcosmogônicas de seus modos de vida ancestrais, com isso refletimos nessa vivência a importância destacada por Dardel (2011) em sua obra "O homem e a terra".

Nos relatos de Xowa Oro Mon (2017): a primeira narrativa reporta-se à relação homem com a natureza e as consequências sofridas pela floresta após o contato com a sociedade envolvente:

A natureza é para nós como se fosse o nosso pai, a nossa mãe. Nós índios gostamos muito do mato. A gente gosta mesmo. Antigamente quando a gente queria comer uma fruta a gente subia e tirava pra comer, não tem necessidade de derrubar a planta. A castanheira dá sombra, dá muita saúde a terra a folha da castanheira, porque a castanheira é grande. Nós dormíamos e comia embaixo das árvores. Por isso que a gente gosta da natureza. Agora não, quando os brancos chegaram aqui e os madeireiros, não entenderam que a madeira sofre. Estão derrubando, estão matando cada vez mais a natureza. A madeira da natureza está se acabando, a castanheira a mesma coisa. A natureza tem saúde também, como a gente tem saúde. É a mesma coisa. A natureza respira como a gente tá respirando. Era para ter muito peixe no rio. Antigamente eu matava um tucunaré que dava pra família toda comer. Nós matávamos os peixes, cortava e botava numas folhas grandes para assar e todo mundo comia, umas duas mil pessoas. Hoje em dia, não. Você vê tem tanto pescador aí que pega mil quilos de peixe e querem ganhar muito com isso.

Os fatores exógenos à coletividade Wari' prosseguem descritos por Xowa Oro Mon (2017) que após demonstrar sua insatisfação quanto ao modo dos não indígenas tratarem a floresta, nos mostra dois cenários distintos da saúde indígena, ao abordar sobre o surgimento de doenças que acometeram seu povo após o contato, e como viviam antes de serem vitimados por essa aproximação com agentes externos:

Antes de o branco chegar não tinha doença grave como está tendo agora. Não tinha dor de barriga, não tinha vômitos, tosse, sofrimento, catapora. Não tinha essas coisas no mato. Não era assim quando a gente vivia no mato. Sabe por que a gente tá morrendo, porque a doença é da cidade. A doença é do branco. A 
gente pegou tudo. De onde vem esse veneno? Vem do açúcar, do sal, bebida, fumo. Tudo isso traz doença pra gente. Quando nós vivíamos no mato, a gente não tinha essas coisas. Você ver agora, o que é que os nossos índios aprenderam com os brancos? Branco ensina a gente a beber, ensina fazer besteira, ensina roubar, um bocado de coisas. Se fosse como o índio vivia no mato, seria muito melhor, porque a doença é tudo na cidade. Tem muita gente que rouba, que fuma droga, não sei se já tem índio fumando droga, porque branco ensina, assim como ensinou a gente a fumar o cigarro.

Outro relato seu que o deixa muito triste foi a violência como foram praticamente dizimados pelo homem branco, detalha como era seu habitat anterior e narra a crueldade dos "civilizados" e dos momentos difíceis que passou com sua família na maloca, ainda na infância:

Ali na quinta linha, não sei se vocês conheceram ou vão conhecer ainda, ali era uma maloca velha, maloca do Oro Waran. O pessoal saía daqui para pescar La nas pedras de Guajará. Nossos índios levavam as cestas para trazer os peixes, que quando o rio começava a vazar, ficava tudo preso nas pedras. Só que os brancos começaram a chegar, matava o índio pra ficar no lugar do índio. Não era pra ser assim. Os cara vieram aqui e atacaram o pessoal. Mataram não sei quantos índios. Foram chegando e afastando a gente cada vez mais para trás. Mataram muito índio, não foi pouco não. Os brancos matavam todos os pais, todas as mães. Depois pegavam as crianças, jogavam para cima e aparava com a faca, que maldade. Eu conto isso porque eu vi essa arrumação. Não era pra fazer isso. Um dia esses caras foram atacar a minha maloca, quando eu tinha dez, doze anos, eu acho, por aí assim. Aí atacaram minha maloca, mataram não sei quantas pessoas, nesse dia minha mãe foi morta por um tiro. Aí o chumbo pegou aqui no meu braço, aqui não tem osso, aí ficou chumbo aqui. Aí meu pai teve que fugir pra outra maloca, chamada Oro Eo, meu pai foi pra lá. Tinha um pajé lá. Curou o lugar do chumbo, mas não é doença para o pajé curar. Por que é outro gosto, sentir o gosto do chumbo é um veneno pra ele. Pajé não cura esse tipo de doença, porque o chumbo fede, é outro cheiro pro pajé. Se fosse a doença mesmo, pajé cura.

A sua última parte do seu relato diz respeito a convivência dos pajés e aborda sobre a atuação xamânica no processo de cura das doenças e como se manifestavam os espíritos diante do fatídico encontro entre vida e morte:

O pajé naquele tempo era assim. O espírito mal botava doença na gente, em qualquer canto, nos pés, no peito, na cabeça, no ombro. Então o pajé vai lá curar essa doença do espírito mal. O pajé ver, aí o pajé fala que dá de curar. O pajé vai e cura. Fica bom. Tem pajé que tira a doença de dentro da barriga, do pulmão, do coração, porque o pajé vê. Porque o espírito do bem faz ver a doença no 
corpo de uma pessoa. Então o pajé cura aquela doença, tira essa doença e a pessoa fica boa. Porque que ele tira? Porque o espírito bom cura e ajuda tirar essa doença do corpo dessa pessoa. $\mathrm{O}$ espírito mal não, o pajé quando não dá de curar aquela doença, a pessoa morre. Então, esse pajé sofre muito, Sabe por que pajé tanto sofre? É assim, esse espírito que ele quis trabalhar com ele junto, para curar a pessoa doente, e se pajé não curar essa doença direito, se não tirar bem a doença, aí esse espírito dele, que tá trabalhando junto com ele, castiga o pajé, e o pajé sofre muito. Esse espírito que tá trabalhando junto com ele, castiga ele. Aí a pessoa morre e o pajé pode morrer também. Sabe por que ele morre? Porque o espírito mal não tá trabalhando direito com ele.

As características mencionadas, tais como, a roda de conversa, a criação mitológica, as artes ancestrais e o cosmopolitismo interétnico, são aspectos que possuem elementos e fenômenos, os quais mantém estreita vinculação com os "marcadores territoriais estruturantes", e que, destarte, contribuem significativamente para a manutenção da memória e a busca por estratégicas que possibilitam a valorização e o fortalecimento da identidade Wari'.

\section{A identidade Wari' como "marcador territorial estruturante"}

No contexto de seus dinamismos ritualísticos-ancestrais e de suas singularidades cosmogônicas, constitui-se como espaço de ação, uma vasta rede de valores originários que simboliza e fortalece com autenticidade a sua peculiar identidade cultural (CASTELLS, 2008). É neste cenário de heterogeneidades socioespaciais, apesar de ataques etnocidas, que consideramos a identidade Wari', como relevante "marcador estruturante", na afirmação de Almeida Silva (2015a, p. 71) como decorrente das

[...] relações estruturantes nos "marcadores territoriais" produzem e desenvolvem mecanismos específicos que codificam as relações cosmogônicas e suas variáveis como espiritualidade, experiências socioespaciais ou vivência, articulação social e política, economia, parentesco, externalidade, internalidade, através do espaço de ação como construções simbólicas responsáveis pela instituição da espacialidade ou territorialidade.

O referido autor encontrou em Henriques (2003, 2004), algumas identificações de marcadores - embora Henriques não desenvolvesse o conceito, entretanto tenha proposto uma estrutura hierárquica de como esses se organizam. A partir de tais apreensões, consideramos no nosso entender, como de considerável importância no embasamento esquemático de suas investigações, e aprofundou a análise iniciada pela autora dos "marcadores territoriais Vivos; Simbólicos; Fabricados; Históricos; Musicais e Funcionais".

Para além disso, Almeida Silva (2010; 2015a), elaborou o conceito de "marcador territorial", o qual nos trouxe relevante contribuição nos estudos sobre às 
territorialidades e coletividades humanas, e especialmente às indígenas. Consideramos que as representações simbólicas étnicas são precisas como "marcadores territoriais estruturantes": Linguísticos; Cosmogônicos; Perceptovisual-sensoriais e Estéticocorporais, além dos "estruturadores" anteriormente descritos.

Em conformidade com o autor, o marcador linguístico "proporciona um universo de representações e formas simbólicas e presentificações que permitem a realização da comunicação" (2015a, p. 102); os cosmogônicos, "organizam a vida coletiva por meio dos valores cosmogônicos, morais e espirituais" (p. 104); os perceptovisual-sensoriais, "fundam-se na materialidade, imaterialidade e no inatingível como se constata nos odores, sons e ruídos [...]" (p. 105); e os estéticocorporais, "são aqueles que têm relação direta com o indígena, representam a própria identidade cultural que carrega no corpo e no espírito e revela a relação íntima com a espiritualidade" (p. 106).

A identidade Wari' possui significativa relação com os "marcadores estruturantes" identificados e caracterizados por Almeida Silva (2010; 2015a). Os "estéticocorporais" podem estar representados nas pinturas feitas com urucum e jenipapo para os preparos das festas do Tamara, Huroroin e Hwitop, ou nas pinturas de enfrentamento das expedições de guerra contra os inimigos (wijam).

Os perceptovisual-sensoriais estão presentes no vento (hotowa), no som do towa, nos cheiros da roça (xitot) e do corpo (kwere-), nas premonições da chegada do estranho (wijam), nas batidas das brigas de borduna (mixita), no cantar das aves (me), no zumbido das abelhas (tawi) e numa infinita rede de simbologias materiais e imateriais que contextualiza a identidade Wari'.

Suas canções ancestrais e de rituais funerários, assim como os assovios ritualísticos que anunciam as festividades e ritualidades, consideramos como "marcadores linguísticos" Wari', enquanto suas cosmogonias, mitologias e práticas xamanísticas ancestrais vislumbram como "marcadores cosmogônicos".

Destarte, encontramos nos "marcadores" o aporte teórico na perspectiva de melhor nos situarmos diante da temática da identidade Wari', pois para Almeida Silva (2015a, p. 207) "a lógica da construção da territorialidade e dos marcadores territoriais indígenas consiste em estruturas estruturantes, alicerçadas na cosmogonia e nas experiências socioespaciais inseridas na cotidianidade de seu espaço de ação".

\section{Considerações não conclusivas}

Os Wari' atravessaram durante décadas uma série de atrocidades que trouxeram profundas transformações em seu modo de vida. Os impactos procedentes da sociedade envolvente resultaram numa espécie de metamorfose identitárias: parte da população morreu em decorrência de doenças e confrontos no período do contato, além de constantes ameaças em seu território pelos mais distintos atores sociais (latifundiários, 
madeireiros, dentre outros), bem como da ausência do Estado no quesito proteção territorial desde os tempos do SPI.

Por outro lado, procuram desenvolver estratégias que possibilitem a valorização e fortalecimento cultural - a escola parece ser um dos caminhos possíveis - mas são conscientes que o retorno à originalidade vivida pelos ancestrais é algo quase impossível em decorrência da realidade que se coloca, compreendem ainda que apesar dos desdobramentos do contato algumas das ações promovidas pelo não indígena foram relevantes até mesmo para assegurar a sobrevivência como povo. Em nossa pesquisa procuramos esclarecer no bojo desta pesquisa através dos marcadores territoriais.

Merece destacar que a compreensão da realidade colocada no século XXI com a "modernidade" é algo que as pessoas mais idosas do povo Wari" observam com ressalvas e preocupações, enquanto os mais novos - muitos dos quais perderam, em conformidade com o que afirmam, grande parte o idioma originário - aceitam com menor resistência esse processo.

Para além disso, pode ser constatado que a sociedade brasileira ainda insiste em promover o apagamento de seus sítios simbólicos, bem como a realização de verdadeira dilaceração de valores identitários, e a supressão de direitos constitucionais em meio a um conjunto de estereótipos, estigmatizações e violências, que tentam negar ou escamotear as ancestrais experiências socioespaciais desse povo originário.

O processo de evangelização e sua particular relação com a identidade Wari' prossegue e constitui-se como palco de discussões promovidas com intensidade por diversos autores de áreas como a Sociologia, Antropologia, Direito, Linguística, dentre outras, as quais se dedicam aos estudos dessa problemática, considerada de difícil contorno, devido a distintos modos de análises, posturas e procedimentos teóricometodológicos.

O encontro da ancestralidade com os agentes exógenos propicia a necessidade de se persistir com estudos investigativos, todavia, deve-se atentar para que se priorizem os interesses dessa coletividade, especialmente, com respeito a seus valores sociais, culturais, espirituais, dentre outros. Há um longo trajeto a ser percorrido, no sentido de entendermos um pouco mais sobre os povos originários. A geografia e outras áreas do conhecimento podem oportunizar esses desenlaces, não somente como modelos teóricos, mas que propiciem debates e apontem caminhos possíveis de diálogos.

Por fim, afirmamos que o estudo dos "marcadores territoriais" é uma relevante contribuição no âmbito do entendimento da apreciação analítica voltada a essas coletividades, os quais resistem e se adequam às transformações produzidas e difundidas pela sociedade envolvente. São atores sociais metamorfoseados no espaço e tempo em seus territórios, e como a identidade não é estática, superam determinadas rupturas e constroem caminhos e perspectivas no seu dinâmico e fundamental processo de autonomia. 


\section{Referências}

ALMEIDA SILVA, A. Impactos socioculturais em populações indígenas de Rondônia: estudo da nação Jupaú. Dissertação (Mestrado em Geografia). Porto Velho: PPGG/UNIR, 2007. $255 f$.

ALMEIDA SILVA, A. Territorialidades e identidade dos coletivos Kawahib da Terra Indígena Uru-Eu-Wau-Wau em Rondônia: "Orevaki Are" (reencontro) dos "marcadores territoriais". Curitiba, 2010. Tese (Doutorado em Geografia) Universidade Federal do Paraná, UFPR. 301f.

ALMEIDA SILVA, A. A questão indígena em Rondônia e os projetos de desenvolvimento na Amazônia Ocidental. Ciência Geográfica, v. XVI, p.8-14, 2012. Bauru: AGB, 2012. Disponível em: http://www.agbbauru.org.br/publicacoes/revista/anoXVI_1/agb_xvi1_versao_internet/A GB_abr2012_02.pdf. Acessado em 28 fev 2019.

ALMEIDA SILVA, A. Territorialidades, identidades e marcadores territoriais Kawahib da Terra Indígena Uru-Eu-Wau-Wau em Rondônia. Jundiaí: Paco Editorial, 2015a.

ALMEIDA SILVA, A. Entre a floresta e o concreto: os impactos socioculturais no povo indígena Jupaú em Rondônia. Jundiaí: Paco Editorial: 2015b.

BACHELARD, G. A poética do espaço. São Paulo: Martins Fontes, 1989.

BRASIL. Quantos são? Ministério da Saúde/SESAI/SIASI. (2014). Disponível em: https://pib.socioambiental.org/pt/Povo:Wari'. Acessado em 10 jun 2018.

BRASIL. Dados populacionais. Guajará-Mirim: Ministério da Justiça/FUNAI, 2017.

CANCLINI, N. G. Culturas Híbridas: estratégias para entrar e sair da modernidade. 4. ed. São Paulo: EdUSP, 2008.

CASSIRER, E. Linguagem e mito. 3.ed. São Paulo: Perspectiva, 1992 [1925].

CASSIRER, E. A filosofia das formas simbólicas. Vol. I. A linguagem. São Paulo: Martins Fontes, 2001 [1926].

CASSIRER, E. A filosofia das formas simbólicas. Vol. II. O pensamento mítico. São Paulo: Martins Fontes, 2004 [1926].

CASSIRER, E. The Philosophy of symbolic forms. Vol. III. The Phenomenology of Knowledge. New Haven: Yale University Press, 1953-1957 [1929].

CASSIRER, E. Las ciencias de la cultura. 2. ed. México: Fondo de Cultura Económica, 2005 [1942].

CASSIRER, E. Antropología Filosófica: Introdução a uma filosofia de la cultura. 5.ed. México: Fondo de Cultura Económica, 1968 [1944]. 
CASSIRER, E. Uma chave para a natureza do homem: o símbolo. In: CASSIRER, E. Antropologia filosófica. São Paulo: Mestre Jou, 1978 [1944].

CASSIRER, E. Ensaio sobre o homem: introdução a uma filosofia da cultura humana. São Paulo: Martins Fontes, 1994 [1944].

CASSIRER, E. O Mito do Estado. Rio de Janeiro: Zahar, 1976 [1946].

CASSIRER, E. Indivíduo y Cosmos en la filosofia del Renascimiento. Buenos Aires: Emecé, 2005 [1951].

CASSIRER, E. Esencia y efecto del concepto de símbolo. México: Fondo de Cultura Económica, 1975 [1956].

CASTELLS, M. O poder da identidade. São Paulo: Paz e Terra, 2008.

CONKLIN, B.A. Sistema de crenças e práticas médicas: o sistema médico Wari' (Pakaanóva). In: SANTOS, R.V.; COIMBRA JR., C.E.A. (Orgs). Saúde e povos indígenas. Rio de Janeiro: Fiocruz, 1994. p.161-186.

http://books.scielo.org/id/wqffx/pdf/santos-9788575412770-08.pdf. Acessado em 30 jun 2018.

DARDEL, E. O homem e a terra: natureza da realidade geográfica. São Paulo: Perspectiva, 2011.

GALLOIS, D. T.; GRUPIONI, L. D. B. O índio na Missão Novas Tribos. Versão preliminar. Departamento de Antropologia da Universidade de São Paulo. Disponível em: https://acervo.socioambiental.org/acervo/documentos/o-indio-na-missao-novastribos-versao-preliminar-301195. Acessado em: 08 ago. 2018. São Paulo. Acervo ISA: 30/11/1995.

GALLOIS, D. T.; GRUPIONI, L. D. B. O índio na Missão Novas Tribos. In: WRIGHT, R. (Org.). Transformando os Deuses: os múltiplos sentidos da conversão entre os povos indígenas no Brasil. Campinas: EdUnicamp, 1999. p.77-129.

HENRIQUES, I. C. Território e Identidade: o desmantelamento da terra africana e a construção da Angola colonial (c.1872-c1926). Sumário pormenorizado. Lisboa:

Faculdade de Letras da Universidade de Lisboa, 2003. p.1-27.

HENRIQUES, I. C. Território e Identidade: a Construção da Angola Colonial. Lisboa: Universidade de Lisboa, 2004.

HOEBEL, E.A. e FROST, E.L. Antropologia Cultural e Social. 7.ed. São Paulo: Cultrix, 2005 [1976].

LOUREIRO, J.J.P. Cultura Amazônica: Uma poética do imaginário. São Paulo: Escrituras, 2001.

ORO MON, X. Entrevista 3. Guajará-Mirim, Agosto/2017. 
ORO NAO, S. Tokwa: a festa da chicha do Povo Oro Nao. Terra Indígena Pacaás Novos. (Trabalho de Conclusão de Curso em Educação Intercultural). Ji-Paraná: Departamento de Educação Intercultural/UNIR, 2016. 19f.

ORO WARAN, F. Entrevista 1. Guajará-Mirim, Agosto/2017.

PACHECO DE OLIVEIRA, J. Situações de fronteira e formas de lidar com a alteridade. Aula inaugural. Manaus: PPGAS/UFAM, 21/03/2019.

SAHLINS, M. "O 'pessimismo sentimental' e a experiência etnográfica: porque a cultura não é um 'objeto' em via de extinção (parte I)". Mana Estudos de Antropologia Social, Museu Nacional. Rio de Janeiro, v.3, nº 1, UFRJ, 1997. p. 41- 73.

SAHLINS, M. "O 'pessimismo sentimental' e a experiência etnográfica: porque a cultura não é um 'objeto' em via de extinção (parte II)". Mana Estudos de Antropologia Social, Museu Nacional. Rio de Janeiro, v.3, nº 2, UFRJ, 1997a. p. 103-150.

SAHLINS, M. Ilhas de História. Rio de Janeiro: Jorge Zahar, 2003 [1985].

STRATHERN, M. O Gênero da Dádiva: problemas com as mulheres e problemas com a sociedade na melanésia. Campinas: Editora Unicamp, 2006.

SURUI, G. Entrevista 2. Guajará-Mirim, Agosto/2017.

VILAÇA, A. Comendo como gente. Rio de Janeiro: Mauad X, 2017.

VILAÇA, A. Quem somos nós: Os Wari' encontram os brancos. Rio de Janeiro: EdUFRJ, 2006.

VILAÇA, A. Conversão, predação e perspectiva. Maná, 14(1): 173-204, 2008.Disponível em http://www.scielo.br/pdf/mana/v14n1/a07v14n1.pdf. Acessado em 08 ago 2018.

VILAÇA, A. Indivíduos celestes - Cristianismo e Parentesco em um grupo nativo da Amazônia. Revista Religião e Sociedade, 27 (I): 11-23, 2007. Rio de Janeiro, 2007.

\section{Agradecimentos}

Estudo desenvolvido com fomento da Fundação de Amparo ao Desenvolvimento das Ações Científicas e Tecnológicas e à Pesquisa do Estado de Rondônia - FAPERO. Projeto "Geografia e Marcadores Territoriais: Sentidos e Representações Socioculturais Amazônicas" - CHAMADA 003/2017 - PQR. Ao Programa de PósGraduação Mestrado e Doutorado em Geografia da Universidade Federal de Rondônia - PPGG/UNIR pelo apoio.

Ao Prof. Dr. Daniel Belik, bolsista do PNPD/CAPES junto ao PPGG/UNIR, pela tradução em língua inglesa e ao mestrando do PPGG/UNIR Charlot JN Charles pela tradução em língua francesa. 


\section{Francisco Marquelino Santana}

Doutor em Geografia pelo PPGG/UNIR. Pesquisador do Grupo de Estudos e Pesquisas Modos de Vidas e Culturas Amazônicas - GEPCULTURA/UNIR. Mestre em Ciências da Linguagem pela UNIR.

Campus José Ribeiro Filho - BR 364, Km 9,5. Zona Rural - CEP 76801-059- Bloco $1 \mathrm{~T}$ - Porto Velho - RO.

E-mail: marquelino@hotmail.com

\section{Josué da Costa Silva}

Pós-Doutor em Geografia pela UEL. Doutor e Mestre em Geografia pela USP. Docente Titular no Departamento de Geografia e do PPGG/UNIR. Pesquisador-Líder do GEPCULTURA/UNIR.

Campus José Ribeiro Filho - BR 364, Km 9,5. Zona Rural - CEP 76801-059- Bloco $1 \mathrm{~T}$ - Porto Velho - RO.

E-mail: jcosta@unir.br

\section{Adnilson de Almeida Silva}

Pós-Doutor em Geografia pela UEPG. Doutor em Geografia pela UFPR. Docente Associado no Departamento de Geografia e do PPGG/UNIR. Líder do Grupo de Pesquisas Geografia, Natureza e Territorialidades Humanas - GENTEH/UNIR.

Campus José Ribeiro Filho - BR 364, Km 9,5. Zona Rural - CEP 76801-059- Bloco $1 \mathrm{~T}$ - Porto Velho - RO.

E-mail: adnilson@unir.br

Recebido para publicação em maio de 2019 Aprovado para publicação em novembro de 2019 